SOSYAL POLITIKA CALISMALARI DERGISI YIL: 15 SAYI: 34 TARIHH: OCAK-HAZİRAN 2015 SS: 27-39 ISSN: 2148-9424

DOI: http://dx.doi.org/10.21560/spcd.90192

\title{
FARKLI KÜLTÜREL ORTAMLARA GÖÇTE YAŞANILAN KAYGI VE BELIRSIZLIIK SORUNU
}

ve Bu Sorunların Çözümü İçin Halkla İlişkiler Çalışmalarına Odaklanma

Öğr. Gör. Engin ÇELEBİ ${ }^{1}$

Öz

Son yıllarda yapılan kültürler arası çalışmalarda halkla ilişkiler uygulamaları önem kazanmaya başlamıştır. Bu çalışma, farklı kültürel ortamlarda ilişki geliştirme stratejilerinin nasıl kaliteli ilişkilere katkı sağladığını açıklamakta ve halkla ilişkiler ile kaygı ve belirsizlik yönetimi literatürünü genişleterek göç eden kişilerin kaygı ve belirsizlik sorunlarının çözümünde halkla ilişkilerin arabuluculuk etkilerini açılayan sonuçlar önermektedir. Ayrıca bu çalışmada, kaygı ve belirsizlik yönetimi için yapılacak çalışmaların göçmenler üzerinde nasıl uygulanacağı da anlatılmaktadır.

Anahtar Kelimeler: halkla ilişkiler, kaygı ve belirsizlik yönetimi, kültürler arası iletişim, göç, ilişki yönetimi

I Öğretim Görevlisi, Çukurova Üniversitesi İletişim Fakültesi. 
THE PROBLEM OF EXPERIENCED ANXIETY AND UNCERTAINTY DURING MIGRATION TO DIFFERENT CULTURAL ENVIRONMENTS

\author{
and Focusing on Public Relation Studies for Solution of this Problem
}

\begin{abstract}
In recent years, public relation practices have gained importance in intercultural works. This study explains how relationship development strategies contribute to quality relationships in different cultural environments, and suggests results by explaining the mediation effects of public relations on the solution of anxiety and uncertainty problems of people who migrate, through broadening the literature of public relations, and anxiety and uncertainty management. The study also describes how the studies performed for anxiety and uncertainty management can be applied to the migrants.
\end{abstract}

Keywords: public relations, anxiety and uncertainty management, intercultural communications, migration, relationship management

\title{
Giriș
}

Politik ve sosyoekonomik etmenler farklı kültürdeki insanları bazen isteyerek bazen de zorunlu olarak bir araya getirmektedir. Farklı dil, din, ırk, sinıf ve mezheplerden gelen kişi veya grupların birbirleriyle etkileşimleri giderek artmaktadır ve farklı kültürel ortamlarda yaşanan kaygı ve belirsizlik sorunu üzerinde durulması gereken bir konu hâline gelmiştir.

Yeni bir yere göç eden herkesi tedirgin eden kaygı ve belirsizliği yok etme konusunda bilgiye ihtiyaç duyulmasına rağmen, farklı kültürel ortamlara göç edecek kişiler için bu bilgi çok daha önemlidir. Çünkü bu kişilerin kaygı ve belirsizlik konusundaki tecrübesi sadece kişisel ve ülkesel seviyede değil, aynı zamanda kültürler arası farklılıktan da kaynaklanmaktadır. Farklı kültürel ortamlarda göçmenler sadece farklı yasalar ve kurallarla düzenlenmiş yönetim sisteminden değil, aynı zamanda farklı kültürel anlayışa sahip kişiler yüzünden de birçok sorunla karşılaşıyor. Farklı kültürel ortamlara göç edenler, ev sahibi ülke hakkında farklı algılara sahip olabilirler ve kendi içlerinde ortak noktada uzlaşmada anlaşamayabilirler. Bu da ev sahibi ülkelerin kendilerine sığınan tüm göçmenlere karşı ortak yaklaşımını zorlaştırır. Bu yüzden, ev sahibi ülkeler farklı kültürel geçmişleri olan göçmenlere farklı davranmak zorundadır.

Kültürler arası halkla ilişkiler çalışmalarında kaygı ve belirsizlik yönetimi iletişimin etkinliğini ve kültürler arası uzlaşmayı kültürel, kişisel ve ülkesel seviyede düzenler. İlişki geliştirme stratejilerini ve bunların halkla ilişkiler 
çalışmaları sonucuna etkisini anlamada kaygı ve belirsizlik yönetimi ile ilgili bazı özel ilişki geliştirme stratejileri etkili sonuçlara ulaşılmasını sağlayabilir. $\mathrm{Bu}$ çalışma, halkla ilişkilerde ilişki geliştirme stratejilerinin arzu edilen ilişkisel sonuçlara nasıl ulaşıldığının altında yatan stratejileri araştırarak kaygı ve belirsizlik yönetimini halkla ilişkiler bağlamında kültürler arası göç sorununa uyarlayacaktır. Aynı zamanda, halkla ilişkilerde ilişki geliştirme stratejilerinin ev sahibi ülke vatandaşlarının ve göçmenlerin kaygı ve belirsizliği üzerinde nasıl fonksiyonlarda bulunacakları da açıklanmaya çalışılacaktır.

Halkla ilişkiler gelişime açık bir iletişim yöntemidir. Halkla ilişkilerde ilişki geliştirmenin amacı, karşılıklı ilişkisel memnuniyet arayışında çift yönlü iletişim ile doğru ve tam bilgiye dayalı bir anlayış geliştirmektir. Bu yüzden halkla ilişkiler çalışmaları toplumsal tutum ve davranışları kurmak, pekiştirmek veya değiştirmek için ve ülkelerin kendi vatandaşlarıyla ve göçmenlerle olan mevcut ilişkisel memnuniyetini ve itibar algılarını güçlendirmek için gereklidir. İlişkisel memnuniyet ve itibarın ülkeler için kamuoyu desteği oluşturduğu ve faydalı göçmen davranışlarını etkilediği kabul edilen bir yaklaşımdır.

Halkla ilişkiler çalışmaları ev sahibi ülke içinde göçmenlerin iyiörgütlenmesine, ülkelerin misyon ve vizyonunun iyi anlatılmasına, vatandaşlar, göçmenler ve sosyal çevre arasında çatışma ve iletişimsizliğin yok edilmesine, kamuoyuyla etkin bir bilgi alışverişi olmasına ve sosyal ilişkiler kurulmasına yardımcı olmaktadır. Bu yüzden, uzun dönemli bir ikna ve güven yaratıcı iletişim süreci olan halkla ilişkiler çalışmalarında ev sahibi ülke vatandaşlarının ve göçmenlerin gereksinimleri doğru tespit edilmeli ve yapılacak halkla ilişkiler çalışmalarında farklı uygulamalar geliştirilmeli, eksikler anında ve zamanında giderilmeli ve halkla ilişkiler çalışmalarında doğru iletişim araç ve yöntemleri kullanılmalıdır.

Halkla ilişkiler çalışmalarında göçmenlerin ev sahibi ülkeye yönelik önceden var olan çağrışımları da göz önünde bulundurulmalıdır. Ülkelerin amaçlarına göre, halkla ilişkiler uygulayıcıları göçmenlerin önceki çağrışımlarını değiştirecek veya güçlendirecek bir halkla ilişkiler stratejisi belirlemelidir. Bu tür stratejilerde ülkesel mesajlar etkili ve tutarlı bir iletişim stratejisiyle zaman içinde oluşturulabilir ve güçlendirilebilir. Ayrıca halkla ilişkiler uygulamaları ülkelerin ekonomik, sosyal ve politik gerçeklerine uygun yapılmalıdır. Bunları yaparken ev sahibi ülkeler kendi vatandaşlarının hedef ve önceliklerini göçmenlerden ayıramayacağını ve göçmenleri kendi toplumundan izole edemeyeceğini anlamalıdırlar ve tüm göçmenlerle ilişkilerini sürdürmelidirler. 


\section{Külltuirrel Uyum}

Kültürler arası uyum için farklı kültürel ortamda olan bir kişi kendisini sosyal olarak rahat ve iletişimsel olarak etkili hissetmek durumundadır (Gudykunst, 1998). Bu yüzden, farklı kültürel ortamlara girmede kaygı ve belirsizliğin azaltılması veya yok edilmesi için ev sahibi ülkenin kültürel değerlerinin bilinmesi gereklidir. Farklı bir kültürel ortama girme kaygısı olan kişiler, farklı kültüre ya da etnik gruba ait kişilerle karşılaştıklarında kendilerini belirsiz bir durum içinde hissederler. Bu ise göçmenlerin kaygı düzeylerinin daha da yükselmesine neden olur. Bu tür ortamlarda göçmenlerin gideceği ülke hakkında yetersiz bilgiye sahip olması belirsizlik hissetmesi ve kaygı yaşamasına neden olur. Kişilerin eğitim düzeyleri, meslekleri ve kültürel farklılıklarından kaynaklanan algılama düzeyleri ile doğruları ve yanlışlarının farklı olması, farklı bir kültürel ortama göç edenler için nasıl davranması gerektiği konusunda bir kaygı ve belirsizlik yaratabilir.

Kültürün, halkla ilişkiler faaliyetlerini etkilediği ve halkla ilişkilerin de kültürün değişimine yardımcı olduğunu söylemek mümkündür (Ural, 2005, s. 218). Farklı kültürel ortamlarda kişiler ev sahibi ülkelerin kültürleri hakkında yeterli bilgiye sahip olurlarsa daha doğru bir tutum ve davranış sergileyebilirler, bu ise kaygı ve belirsizliğin azaltılmasına yardımcı olacaktır. Göç etme konusunda kişilerin istekleri ile göç edeceği ülke hakkında bilgi sahibi olma ve o ülkeye güven duyma arasında doğru orantılı bir ilişki vardır. Bu yüzden göçmenlerin kaygı ve belirsizlik seviyelerine nüfuz edebilecek hangi etmenlerin olduğunu bilmek çok önemlidir. Demografik bilgiler, göçmenlerin geldikleri ülkeler, dil engeli ve ev sahibi ülkede geçirilen süreler ve geçmiş deneyimler kaygı ve belirsizlik seviyesi içinde değişkenlik gösterebilir. Bunun yanı sıra sosyal uyum gibi psikolojik deneyimlerle, rol çatışmaları, kültürel ve coğrafi farklılıklara alışmada karşılaştıkları zorluklarda önemli konulardır. Özellikle sosyal destek aramak için danışmanlık hizmetleri gibi özel kişi veya kurumların nasıl yardım edeceği gibi yöntemler, belirsizlik ve kaygıyı azaltmak için göçmenlere yardımcı olmaya çalışmaktadır. Ancak kaygı ve belirsizlik ile mücadele eden göçmenlere yardım etmek için kurumlar göçmenlerle olan ilişkilerinde göçmenleri genel anlamda tek tip olarak görürler. Ancak aynı ülkeden gelmiş olsalar dahi farklı kültürlere sahip olan göçmenler kaygı ve belirsizlik çözümünde sorunları aynı şekilde algılayan ve beraber çalışan homojen bir sosyal bütünlüğü temsil edemeyebilirler.

Göçmenlere yönelik kültürel uyum çalışmaları önemi giderek artan bir konu hâline gelmiştir. Göçmenlerle kurulacak iletişim sadece onlarla diyalog kurmak 
için değil, göçmenlere yönelik stratejilerin gelişimi ve onların kültürel eğitimi için de gereklidir. Ülkelerin göçmenleri ile olan iletişimsel faaliyetlerinin kültürel uyumları üzerine etkisi ve bu iletişim çalışmalarının göçmenlerin tutum ve davranışlarına yönelik etkilerinin önemi her geçen gün daha iyi anlaşılmaktadır. Göçmenler ile olumlu ilişkiler kurmak ve sürdürmek, göçmenleri ev sahibi ülke ve vatandaşları ile olumlu davranışlarda bulunmaya teşvik edecektir.

\section{Kaygı ve Belirsizlik Yönetiminde Halkla İlișkiler Çalıșmalarının}

\section{Önemi}

Halkla ilişkiler dinamik ve kapsamlı yöntemlerle çalışmalar yapan, bilgi alışverişinde bulunulan, anlam inşa eden ve yöneten, başkalarıyla kazanılan ya da kaybedilen fikir birliği, toplumsal rıza ve meşruiyete yönelik önceden planlanan bir temsil sürecidir (Berger, 1999, s. 186). Halkla ilişkiler çalışmalarının gücü; ülkelerin belirli değerler, kimlikler ve imajlar ile ilgili olarak toplumsal yerini belirleme kapasitesine sahiptir. Bu yüzden ülkeler ve göçmenler ile ilgili belirsizlikler halkla ilişkiler çalışmaları aracılığıyla yönetilebilir. Çünkü halkla ilişkiler çalışmalarında ev sahibi ülke vatandaşları ve göçmenler arasında taraf tutmak amaçlara ulaşmada zorluklar yaratabilir ve etiksel olarak sorgulanabilir. Sosyal sınırlamaların ötesinde bu tür unsurların tümü en iyi şekilde planlandığında ev sahibi ülkeler demokratik ilkelerinin gerektirdiği gibi topluma karşı sorumlu ve göçmenlere karşı cevap verebilir bir yönetim anlayışına sahip olacaktır. Ev sahibi ülke vatandaşları ve göçmenlerle oluşturulacak toplumsal inşa, halkla ilişkiler uygulayıcıları tarafından ülkelere liderlik ve rehberlik edebilecek ve sürdürülecek etkili çabalarla kurulabilir. Bu tür çalışmalarda ev sahibi ülke vatandaşları kadar göçmenler de mutlaka düşünülmelidir.

Küresel veya uluslararası halkla ilişkiler, diğer ülkelerin halklarıyla faydalı ilişkiler kurmak veya geliştirmek için bir şirketin, kuruluşun veya hükümetin yaptığı planlı ve organize edilmiş çabalar olarak tanımlanabilir (Wilcox ve Cameron, 2009, s. 504). Kaygı ve belirsizlik yönetiminde halkla ilişkiler uygulamaları kültürler arası uyum ile ilgili ana süreçleri açılamaya yardımcı olmaktadır. Kaygı ve belirsizlik yönetiminde olumlu halkla ilişkiler sonuçlarını belirsizlik ve kaygının azaltılması belirler.

Kaygı daha çok gelecek ile ilgilidir ve korkunçlaştırma (olayların olası en kötü sonuçları öngörülür), yanlış öngörülerde bulunma (olası tehlike çok 
abartılır), kaba genelleştirmeler yapma (belirli bir olayın göz korkutan yanı bütün diğer olaylar için genelleştirilir), uçlara gitme (tam güvenilir ya da çok tehlikeli), güvenlik (güvenlik sağlayan etkenler ya küçümsenir ya da bunlar hiç göz önünde bulundurulamaz) gibi yanlış yorumlamalarla oluşabilir (Köroğlu, 2011, s. 134). Belirsizlik ise başkalarının düşünce veya davranışlarını veya katılımcıların davranışsal tutumlarını tahmin etmede yetersiz olma durumu olarak tanımlanabilir (Guerrero ve Gudykunst, 1996, s. 50). Belirsizlik, kayg1 düzeyinin yükselmesine yol açar. Kaygı ise formel kurallara daha çok ihtiyaç duyulmasına ve farklı görüşlere daha hoşgörüsüz yaklaşılmasına neden olur (Sriramesh ve White, 2005, s. 635). Belirsizlik, göç ederken veya bir ülke ve vatandaşları hakkında tahminlerde bulunurken güven eksikliği algısını ifade eder. Belirsizlik, rahat etkileşimin olmadığı, başkalarının davranışlarını tahmin etmek için yeterli bilginin olmadığı durumlarda meydana gelir ve bu da can sıkıntısına ve yanlış etkileşime neden olur. Belirsizliği azaltmak, bilinmeyenler hakkında fikir edinmek ve başkalarının duygu ve düşünceleri tahmin etmek için sahip olunan bilgi anlamına gelir. Bu yetenek, belirsizliğin tersi olan, güven yeteneği olarak da ifade edilir. Kaygı ise, Gudykunst ve Hummer’a göre (1988) belirsizlikten farklı olarak daha çok duygusaldır ve olumsuz sonuçların yakalanmasına işaret eder (aktaran Ni ve Wang, 2011, s. 273). Kaygı seviyesi yüksek olduğu zaman insanlar son derece tedirgin olurlar. Bu açıdan halkla ilişkiler çalışmaları, etkili iletişim ve kültürler arası uyum gibi olumlu iletişim sonuçları meydana getirerek kişilerin belirsizlik ve kaygılarını azaltmaya yardımcı olur.

Gudykunst (1998) bir kişinin yabancılarla iletişim hâlindeyken belirsizlik ve kaygı seviyesini tahmin eden yedi faktör tanımlamıştır: benlik kavramı (kişisel ve toplumsal kimliklerin alg1sı), yabancılarla etkileşim için motivasyon (öngörülebilirlik, grup içerme ve sürdürülebilir kimlik ihtiyacı), yabancılara reaksiyonlar (empati, belirsizlik toleransı ve grup içi tutum katılığı), yabancıların toplumsal kategorizasyonu (beklentileri, algilanan benzerlikler ve grup içi bilgi), durumsal süreçler (algılanan grup içi güç ve işbirliği), yabancılarla bağlantıları (cazibe, dayanışma, temasların sayısı ve kalitesi) ve etik etkileşimleri (saygı ve manevi kapsayıcılık) (s. 428). Halkla ilişkiler çalışmalarının etkinliği olumlu iletişim sonuçlarını temsil eder ve bu olumlu iletişim sonuçları başarılı bir belirsizlik ve kaygı yönetimi gerçekleştirerek belirsizlik ve kaygı seviyelerinin azaltılmasina yardımcı olur.

Halkla ilişkiler çalışmaları ülke vatandaşlarına veya göçmenlere değerli sonuçlar temin etmek için bir ülkenin yeterliliğinin genel değerlendirmesi 
olarak ifade edilebilir. Bir ülkenin aynı alandaki diğer ülkelerin özellikleriyle karşılaştırıldığında göze çarpan özelliklerinin ülkelerin itibarı için bir temel oluşturduğu belirtilebilir. Göçmenler daha çok önem verdikleri ayırt edici niteliklere sahip olan ülkelere bağlı olurlar. Ülkelerin toplumsal sorumluluklarını dikkate almadan göçmenlerin gözünde itibar kazanmaları oldukça zordur. Ülkelerin toplumsal sorumluluklarıly ilgili performans gösterebilecekleri kişiler kendi çalışanları, vatandaşları ve diğer sosyal paydaşlarıdır. Halkla ilişkiler çalışmalarının ülke itibarı değerlendirmesinin yanı sıra ülke vatandaşlarının saygınlığının değerlendirmesi üzerinde de doğrudan etkileri olabilir.

\section{İlişki Geliştirme Stratejileri Olarak Halkla İlişskiler Çalışmaları}

İlişki geliştirme stratejilerinden ilişkisel sonuçlara olan etkili süreci açılamayı amaçlayan ve daha önce yapılan birçok araştırma, ilişki geliştirme stratejilerinin ilișkilerin sonuçlarını etkilediğini ortaya koymuștur. Halkla ilișkiler uygulayıcıları ülkeler ve toplumlar arasında çeşitli iletişim ve ilişkisel nitelikleri tespit etmekte ve buna uygun stratejiler geliştirmektedir. Bu açıdan halkla ilişkiler hedef kitlelerle olumlu ilişkiler kuran ve koruyan bir yönetim fonksiyonudur. Etkili bir halkla ilişkiler çalışmasıyla ülkeler kendi vatandaşlarıyla ve göçmenlerle pozitif ilişkiler edinebilirler.

Daha önce yapılan birçok araştırma, ilişki geliştirme stratejilerinin ilişkilerin sonuçlarını etkilediğini ortaya koymuştur. İlişkisel durumlarda ev sahibi ülke veya göçmenlerden her iki taraf da iletişimi başlatabilir. Ev sahibi ülke vatandaşları veya göçmenler ile ilişkide olan herhangi bir ülke için diyalog becerisi gereklidir. Göçmenlerle ilişkisel amaçların gerçekleştirmesini kolaylaştıran veya koruyan her davranış uygun bir davranış olarak değerlendirilir. Bu açıdan bakıldığında halkla ilişkiler çalışmalarını sosyal etkinliklerden farklı bir uygulama olarak ifade edebiliriz.

Halkla ilişkiler çalışmaları ev sahibi ülke vatandaşları ve göçmenlerin her ikisini de içermelidir. Bu alanda yapılacak çalışmalardaki ilişki yönetimi de hem iletişime dayalı ilişki hem davranışa dayalı ilişkiyi vurgulamalıdır. İlişkisel memnuniyet çift taraflı olduğundan eğer bir ülke göçmenlerin istek ve beklentilerine cevap verebiliyor ve onları memnun ediyorsa göçmenlerin bu ülke ile olan ilişkilerinden memnuniyet duyduğu söylenebilir. Bu açıdan ilişkisel memnuniyet, göçmenlerin ev sahibi ülke ile görüş birliğinde olma algısı olarak açıklanabilir. Bu yüzden halkla 
ilişkiler çalışmaları amacının ev sahibi ülke vatandaşları ve göçmenler arasında faydacı ilişkileri yaratmak, sürdürmek ve güçlendirmek olduğu söylenilebilir.

Hon ve Grunig (1999), bir halkla ilişkiler çalışmasını değerlendirmede en çok kabul edilen kriterler olarak güven, karşıllklı kontrol, ilişkisel memnuniyet ve ilişkisel bağllık kriterlerini belirlemişlerdir. Kısaca, güven; kendine güven ve diğer tarafa açık olma isteğidir. Karşıllklı kontrol, ilişkilerin amacı ve davranışsal rutinler hakkında kimin karar vereceği konusundaki anlaşma derecesini ifade eder. İlişkisel memnuniyet, hem kurumun hem de kamunun karşılıklı ilişkilerinden memnuniyet derecesini ifade eder. İlişkisel bağlllık, değerli bir ilişki sürdürmek için kalıcı bir uyumu ifade eder ve iki konuyu içerir: devamlı bağlılık (dayanıklı bir eylem hattı) ve duygusal bağll1ık (bir nesneye devamlı bir duygusal bağlllık).

Halkla ilişkiler alanında yapılan önceki araştırmalar, halkla ilişkiler, kişisel iletişim ve çatışma çözümü modellerinden elde edilen ilişki geliştirme stratejisinin etkilerini ortaya koymuştur. Bu yolla Ledingham ve Bruning (1998) vaat edilenlerin yapılmasını "güven", gelecek ile ilgili planların paylaşılmasını "açıklık", toplumsal dayanışmayı "katılım”, toplum refahının düşünüldügünü "yatırım" ve toplum yararına sadık kalınacağını ise "sadakat" ilişkileriyle belirtmişlerdir. Ledingham ve Bruning, bu beş işlevselleştirilmiş ölçüt ve davranış arasındaki bağın memnuniyetiyle de alakalı olduğunu belirtmişlerdir.

Belirsizlik ve kaygı yönetimi ile yeni bir kültürel ortama adapte olunmasında sorunların ortadan kaldırılması amaçlanmaktadır. Ev sahibi ülkelerin misafirperver stratejileri yeni gelenlerin belirsizlik ve kaygılarının azaltılmasına yardımcı olabilir. $\mathrm{Bu}$ da olumlu iletişim sonuçlarına göre belirlenir. Farklı kültürel ortamlarda, bir ülkenin başarılı ilişki geliştirme stratejileri olumlu halkla ilişkiler sonuçlarını geliştirerek insanların kaygı ve belirsizliklerinin azaltılmasına yardımcı olabilir. Ülkelerin kendi vatandaşlarıyla ve diğer ülke vatandaşlarıyla olan iletişimlerindeki artış kaygı ve belirsizlikte bir azalmaya ve göçmenlerin tutum ve davranışlarını doğru olarak tahmin etmeye yardımcı olacaktır. Ayrıca göçmenler için de uluslararası göçe açı olan ülkelerin davranışları hakkındaki bilgi artışı belirsizlik ve kaygıların azaltılmasına yardımcı olur.

Çoğu araştırma; halkla ilişkiler çalışmalarının erişim, olumluluk, açıklık, yasal güvence, ilişki kurma, görev paylaşımı gibi ilişki geliştirme stratejilerini doğrudan etkilediğini tespit etmiştir (Ni ve Wang, 2011). 
Erişim kanalları ve paylaşılan ağlar belirsizliğin azalmasına doğrudan katkıda bulunur. Belirsizlikteki azalma kültürler arası uyumu ve farklı kültürel ortamlarda iletişimi olumlu olarak etkiler.

Olumluluk; taraflar için ilişkiyi daha memnuniyet verici hâle getirmek için ülkelerin veya kamunun yapacağı her şeyi içerir. Olumluluk; karşılıklı etkileşimi ve ilişkiyi geliştirme arzusu taşır ve karşı tarafın da aynı şeyi yapacağı umudunu yansıtır. Gudykunst (1998), guruplar arası karşılaşmalarda insanların diğerlerinin ilk önce sosyal kimliklerini (ten rengi, kıyafet, aksanlar vb.) tanıma eğiliminde olduğunu ileri sürmüştür. Tanınan grup üyeleri ile olumlu geçmiş tecrübeler, olumlu duygu ve beklentilere neden olur. Özellikle farklı sosyal gruptakilerde olumluluk, birbirlerini nasıl tanıdıklarından ziyade birbirleri hakkında ne hissettiklerine bağlı olarak gelişir. Olumluluğu artan bir ülkenin göçmenlere davranışları konusundaki kaygıları azalır. Kaygıda azalma, kültürler arası ortamlarda ev sahibi bir ülke ile göçmenler arasındaki karşılıklı kontrol, güven, ilişkisel tatmin ve ilişkisel bağlılığı olumlu olarak etkiler.

$A c ̧ ı k l ı k$; duygu ve düşüncelerin ülkeler arasında paylaşılması ve bilgi paylaşımını arttırmak göçmenlerin kaygı ve belirsizliklerini azaltacaktır.

Yasal güvence; bir ülkenin yasal güvencesini arttırmak, göçmenlerin kaygılarını azaltır. Yasal güvencenin ilişki yönetimindeki en önemli strateji olduğu belirtilebilinir. Yasal güvencenin tatmine de doğrudan etkileri olacaktır. Yasal güvence ile göçmenlerin ev sahibi ülke ile temasını arttırdığında potansiyel bir tehdit ve tehlike hissedeceğini algılayıp algılamadıkları ve sorunlarda ev sahibi ülkenin suçu göçmenlere atıp atmayacağı konusundaki algılamaları önemlidir. Yasal güvencenin kaygı ve belirsizlik yönetiminde en önemli madde olduğu belirtilebilinir. Ayrıca göçmenlerin hakkını güvence altına almak, kaygı ve belirsizlik yönetimindeki ahlaki kapsayıcılığa benzer.

Ahlaki kapsayıcılık tarafların eşit olduğu ve her iki tarafın da adil süreçte haklarının bulunduğu ilişkiler olarak tanımlanmaktadır. Başkalarının iyiliğini isteme ve başkalarının iyiliği için fedakârlıkta bulunma isteği gibi. Aksi durumda bireylerin ve grupların etik değer ve düşüncelerin adil uygulandığı sınırların içinde olmadığı zamanlarda ahlaki dışlanma meydana gelir. Ahlaki olarak dışlanmış grubun ve grup üyelerinin çok yüksek seviyede kaygılı olacakları ve ahlaki olarak dışlanan kişilere karşı misafirperver olunamayacağı kabul edilmektedir. Ahlaki dışlama ve gayrimeşrulaştırma yasal güvenceye de karşıdır (Ni ve Wang, 2011). 
İlişki kurma ise bir ülkenin kendi vatandaşlarına yaptığı gibi yabancı gruplarla da ilişki kurması ve iyi niyet geliştirme stratejisi, kaygı ve belirsizlik yönetimindeki paylaşılan değerlerle yakından ilişkilidir. Yabancılarla paylaşılan değerler arttığ zaman kaygı ve belirsizliğin azalacağı düşünülebilir. İlişki kurma ölçümünde; göçmenler ile kurulacak iletişim miktarı, ülke vatandaşları tarafından gösterilen iyi niyet ve destek, ekolojik dengenin korunması gibi paylaşılan ortak sorumluluklar önem kazanmaktadır. "İlişkisel yapı modeli etik, organizasyonlar ve paydaşlar için de kazançlıdır, ayrıca bu organizasyonlara olduğu gibi topluma da en iyi hizmet edebilecek alandır" (Kruckeberg ve Starck, 2004, s. 137).

Görev paylaşımında ise ülkelerin ve göçmenlerin veya her ikisinin de çıkarları ile ilgili ortak veya ayrı problemlerin çözümünde görevlerin işbirliği yapılarak çözülmesi önemlidir. Göçmenlerle olumlu ilişki geliştirmede işbirliği önemli bir faktör olarak ele alınır. Görev paylaşımı ülkelerin göçmenlerle beraber ve göçmenler için yapacakları davranışsal bileşenleri içermektedir. Kamu böyle bir ilişkiyi, ülke göçmenlerin yararı için ne yapar düşüncesine odaklanarak değerlendirir.

Paylaşılan amaçlar, görevler ve kalıcı ilişkiler amaçlayan ve koordine edilmiş hareketleri tanımlayan işbirliği çoğu zaman memnuniyet verici duygulara yol açar. Daha da önemlisi sosyal etkileşimlerde başkalarıyla işbirliği çabaları belirsizlik ve kaygiları azaltabilir (Ni ve Wang, 2011).

Halkla ilişkiler çalışmaları ev sahibi ülke ve göçmenler arasındaki etkileşimde çok önemli bir rol üstlenmektedir. Sürekli etkileşim, göçmenlerin ev sahibi ülkeye olan bağımlılı̆̆ı alanına da katkı sağlamaktadır. Ev sahibi ülkelerin itibarını olumlu algıladığında göçmenlerin büyük bir çoğunluğu başkalarıyla ev sahibi ülke hakkında olumlu iletişim kuracaktır ve olumlu iletişim etkileri ile göçmenler ev sahibi ülkelere yönelik destekleyici davranışlar gösterecektir. Etkili halkla ilişkiler çalışmaları ilişkisel memnuniyeti sürekli etkileşime bağlayan güçlü bir arabulucu işlevi görebilir.

\section{Sonuç ve Öneriler}

Bu çalışma, farklı kültürel ortamlardaki göçmenler için halkla ilişkiler stratejilerinin önemini açılamaya çalışmıştır. İki veya daha fazla kültürel grup arasında tek yönlü karşılaştırmalar yapan kültürler arası çalışmalardan farklı olarak bu çalışma, kültürler arası ortamlara göç eden göçmenlere yönelik yapılacak çalışmalarda halkla ilişkiler ve ilişki geliştirme sürecini açıklamıştır. 
$\mathrm{Bu}$ sonuç ile göçmenlerin farklı kültürel ortamlarda yaşayabileceği kaygı ve belirsizlik sorunu için altı ilişki geliştirme stratejisi ve dört halkla ilişkiler stratejisi arasındaki doğrudan ve dolaylı ilişkiler açıklanmıştır. Amacı, halkla ilişkilerde ilişki geliştirme stratejilerinin kaygı ve belirsizlik yönetiminde ev sahibi ülke vatandaşları ve göçmen ilişkisi sonuçlarını etkilediği konusunda bir değerlendirme yapmak olan bu çalışmada altı ilişki geliştirme stratejisi (erişim, olumluluk, açıklık, yasal güvence, ilişki kurma ve görev paylaşımı) ve dört ilişkisel halkla ilişkiler sonucu (karşılıklı kontrol, güven, tatmin ve bağllık) arasındaki bağların göçmenlerin kaygı ve belirsizlik sorununu doğrudan ve/veya dolaylı bir yolla azalttığı söylenebilir. Ayrıca bu ilişkiler, güven ve tatmini de doğrudan etkiler. Çünkü kaygı ve belirsizliğin tersi güvendir. Kaygı ve belirsizliğin azalımı, göçmenlerin ev sahibi ülkelere olan güven, tatmin ve bağlllı̆̆ın artmasına yol açacaktır.

Uygulayıcılar etkili ilişkisel yönetimi; ortak ilgiler ve paylaşılan amaçlar, ortak anlayışlar ve ev sahibi ülke ile göçmenler arasında kazançlar üretmek etrafında değerlendirmelidirler. Ev sahibi ülkelerin yönetimsel yaklaşımı ve kültürel farklılık konuları gibi alanlarda uygulanan halkla ilişkiler ve ilişki geliştirme çalışmalarında sorumluluk yüklenmesi farklı kültürel özelliklere sahip olan göçmenler üzerinde çok yararlı olabilir.

Kaygı ve belirsizlik hem duygusal hem de bilişseldir. Bilişsel düzey daha çok tarafların davranış ve beklentileri hakkında hissedilen kesinlikle ilgili olabilir (Ni ve Wang, 2011). Bunlar ise göçmenleri doğrudan etkiler. Azalmış kaygı ve belirsizliğin bütün göçmenler üzerinde doğrudan olumlu etkisi vardır. En önemlisi de bunun güven ve bağlllığa doğrudan etkisi vardır ve bu, tatmini de doğrudan etkilemektedir. Duygusal düzey ise ev sahibi ülkeye olan duygusal bağlılığı arttırmaktadır. Bunun için ise iletişimin simetrik hâle getirilmesi ve ev sahibi ülkelerin kendisini göçmenlerin yerine koyarak empati yapması doğru bir yöntem olacaktır. Ayrıca göçmenler, büyük ve etkileyemedikleri bir bürokrasiyle karşılaştıklarında kendilerini zayıf ve önemsiz hissetme eğilimindedirler. Simetrik iletişim, esas olarak bu tür faydasızlıkları hafifleterek ve kaygıyı azaltarak ilişkisel sonuçlara etki eder.

Göçmenlere yönelik çalışmalarda uygulayıcılar hedeflenen ilişkisel sonuçları ve arzu edilen kaygı ve belirsizliğin yok edilmesini sağlamak için halkla ilişkiler stratejilerini kullanabilirler. İlişki kurma biçimlerinin ortam belirsizliğinin azaltılmasında belirleyici bir rolü vardır. Farklı bir kültürel ortama girme kaygısı 
yüksek olan kişilerin ise farklı kültürden olan bireylerle diyalog kurmaktan ve bu tür ortamlara girmekten kaçındıkları görülmüştür. Halkla ilişkiler sonuçlarına etkisi tamamen kaygı ve belirsizlik arabuluculuğuyla olduğu için göçmenlerle ilişki kurma stratejilerini kullanırken ev sahibi ülkeler bu stratejilerin uygulandığı göçmenlerde kaygı ve belirsizlik seviyelerinin ne derece düştüğünü gözlemlemelidirler.

Ev sahibi ülke kurumları halkla ilişkiler ve ilişki geliştirme stratejilerini günlük kullanım bazında değerlendirmemeli, daha çok yönetim stratejisi olarak değerlendirmelidirler. $\mathrm{Bu}$ stratejileri uygularken uygulayıcılar sadece bilgi paylaşıp dinleme yapmadıklarından aynı zamanda göçmenlerin bakış açısıyla düşünüp onların kaygı ve belirsizlik seviyesini düşündüklerinden emin olmak zorundadırlar. Çünkü kaygı ve belirsizlik azalımı göçmenlerin ev sahibi ülkelere ve vatandaşlarına olumlu bakış açısının temel nedenidir.

Halkla ilişkiler çalışmalarında uygulanan ilişkisel yönetim stratejilerinde bahsedilen tüm öneriler göçmenlerin kaygı ve belirsizliklerini yönetmeye ihtiyaç duyan bütün ülkelerde uygulanabilir. Ev sahibi ülke kurumları sosyal hayat, kültürel çatışma ve ayrımcllık gibi en sıkıntılı alanlara odaklanarak ilişki geliştirme stratejilerini geliştirmelidirler. İlişki geliştirme stratejileri uygulandıktan sonraki kaygı, belirsizlik ve ilişkisel sonuçları değerlendirmek için göçmenlerin kaygı ve belirsizlik seviyelerindeki değişimler takip edilmelidir.

Yeni bir kültürel ortam ve uyum süreci içerdiği müddetçe, kaygı ve belirsizlik yönetimi sadece kültürler arası etkileşimlere değil, aynı zamanda aynı kültür etkileşimlerine de uygulanabilir. Çünkü bir ülkenin kendi vatandaşları da farklı seviyelerde kaygı ve belirsizlik yaşayabilirler.

Gudykunst'ın (1998) kaygı ve belirsizlik yönetimi, göç alanına halkla ilişkiler ve ilişki yönetimi (Ledingham ve Bruning, 1998) literatürü açısından Ni ve Wang’n (2011) "Bir Kültürler Arası Ortamda Kaygı ve Belirsizlik Yönetimi: Kurum-Halkla İlişkilerine Etkisi” çalışmasından yararlanarak uyarlanmıştır. Çoğu uygulaması kişilerarası ve gruplar arası seviyede olan kaygı ve belirsizlik yönetimi sürekli gelişen ve değişen bir teoridir ve bu alanda çok az araştırma yapılmıştır (Ni ve Wang, 2011, s. 278). Bu çalışma, bu teoriyi kültürler arası göçler alanına uygulayarak ve ilişki sonuçlarını halkla ilişkiler etkinliğinin ölçüsü olarak kullanarak bu alana yeni bir perspektifle yaklaşmıştır. Yine de halkla ilişkilerde ilişki geliştirme stratejilerinin göçmenler üzerine uygulanması durumunda orijinal kuramın bazı unsurlarının değişebileceği veya kaybolabileceği belirtilebilir. 


\section{Kaynakça}

Berger, B. (1999). The Halcion affair: Public relations and the construction of ideological world view. Journal of Public Relations Research, 11, ss. 185-203.

Gudykunst, W. B. (1998). Applying anxiety/uncertainty management (AUM) theory to intercultural adjustment training. Int. J. Intercultural Rel. 2(22), ss. 227-250.

Guerrero, S. L. ve Gudykunst W. B. (1996-7). A thematic analysis of intergroup communication over time. Intercultural Communication Studies, 2(6), ss. 43-75.

Hon, L. C. ve Grunig, J. E. (1999). Guidelines for measuring relationships in public relations. Erişim tarihi: 20.06.2014, http://www.instituteforpr.org/wp-content/uploads/ Guidelines_Measuring_Relationships.pdf.

Kruckeberg, D. ve Starck, K. (2004). The role and ethics of community building for consumer products and services. Galician, M. L. (Ed.) Handbook of product placement in the media (ss. 133-146). New York: Haworth Press.

Köroğlu, E. (2011). Kaygılarımız korkularımız nedir? Nasıl baş edilir? Ankara: HYB Yayıncilık.

Ledingham, J. A. ve Bruning, S. D. (1998). Relationship management and public relations: Dimensions of an organization-public relationship. Public Relations Review, 1(24), ss. 55-65.

Ni, L. ve Wang, Q. (2011). Anxiety and uncertainty management in an intercultural setting: The impact on organization-public relationships. Journal of Public Relations Research, 3(23), ss. 269-301.

Sriramesh, K. ve White, J. (2005). Toplum kültürü ve halkla ilişkiler. J. E. Grunig (Ed.) Halkla ilişkiler ve iletişim yönetiminde mükemmellik (ss. 603-622). (E. Özsayar, Çev.). İstanbul: Rota Yayınları.

Ural, E. G. (2005). Çok kültürlü ortamlarda halkla ilişkiler. P. E. Yayınoğlu (Ed.) Çok kültürlü ortamlarda halkla ilişkiler, kurumsal iletişim ve yönetim (ss. 203-237). İstanbul: İstanbul Ticaret Üniversitesi Yayınları.

Wilcox, D. L. ve Cameron, G. T. (2009). Public relations: Strategies and tactics. Boston: Pearson Educations. 